\title{
Effects of partial or total replacement of corn cracked grain with high concentrations of crude glycerin on rumen metabolism of crossbred sheep
}

\author{
Eric Haydt Castello Branco van Cleef*, Marco Túlio Costa Almeida, Henrique Leal Perez, \\ Josimari Regina Paschoaloto, Edivilson Silva Castro Filho, Jane Maria Bertocco Ezequiel
}

Department of Animal Science, São Paulo State University, Jaboticabal, São Paulo, 14884-900, Brazil

\section{A R T I C L E I N F O}

\section{Keywords:}

By-product

Glycerol

Greenhouse gas

Metabolism

Sheep

\begin{abstract}
A B S T R A C T
Crude glycerin, a by-product of the biodiesel industry, has been used as a strategic ingredient in intensive ruminant production systems, mainly in substitution of starch-rich ingredients. The present study was performed to evaluate the effects of the inclusion of up to $30 \%$ of crude glycerin in diets for feedlot sheep, on ruminal parameters, such as $\mathrm{pH}, \mathrm{NH}_{3}-\mathrm{N}$ and volatile fatty acids concentrations, in situ degradability, as well as in vitro greenhouse gas production and in vitro digestibility. Eight ruminally-cannulated male Santa Inês $\times$ Dorper sheep $(64.5 \pm 8.5 \mathrm{~kg})$ were distributed in a replicated $4 \times 4$ Latin square design. The experimental diets contained 0 , 10, 20 or $30 \%$ of crude glycerin and were labeled as G0, G10, G20 and G30, respectively. The crude glycerin totally replaced the corn cracked grain in treatment G30. The inclusion of crude glycerin in the diets tended to promote a quadratic effect in DMI, with greater values observed for treatments G10 and G20. Crude glycerin tended to increase the ruminal $\mathrm{pH}$ and $\mathrm{NH}_{3}-\mathrm{N}$, but linearly reduced the total molar concentration of VFA, acetic, butyric, isobutyric and isovaleric acids. Treatments linearly increased in vitro DM digestibility of diets and linearly reduced NDF digestibility. The inclusion of crude glycerin in the diets linearly decreased the in vitro total gas and $\mathrm{CO}_{2}$ production (mL/g degraded) and tented to reduce $\mathrm{CH}_{4}(\mathrm{~mL} / \mathrm{g}$ degraded). A linear increase of soluble fraction in water ("a") of the diets was observed with the increasing inclusion of crude glycerin. The insoluble but potentially degradable fraction ("b") of DM and NDF of the diets were linearly decreased and increased, respectively. The potential ruminal degradation of the diets was markedly and linearly increased with the increasing inclusion of the by-product. The replacement of corn cracked grain by crude glycerin (up to 30\% DM) changes rumen fermentation parameters, decreasing VFA production, in vitro total gas production and $\mathrm{CH}_{4}$. Additionally, the potential and effective degradation as well as in vitro DM digestibility of diets are improved while fiber digestibility is impaired.
\end{abstract}

\section{Introduction}

The use of agroindustry by-products as animal feed is becoming increasingly common throughout the world. The high price of conventional ingredients, such as corn and soybean, has led meat producers to look for alternative ingredients, which usually have a lower purchase cost, but require further understanding of their nutritional value and acceptability (van Cleef et al., 2014).

Crude glycerin, a by-product of the biodiesel industry, is a new welldocumented ingredient, which has been used as a strategic ingredient in intensive ruminant production systems, mainly in substitution of starchrich ingredients, such as corn (Donkin et al., 2009; Carvalho et al., 2015; Almeida et al., 2017; van Cleef et al., 2017). The current annual production of biodiesel in the world is around 34.5 billion liters OECD/
FAO (2016). The Brazil is the second largest biodiesel producer in the world, with 3.8 billion liters, in 2016 (United States lead with 5.5 billion liters), generating around 420 million liters of crude glycerin in 2016 (ANP, 2017), that could be used to feed livestock.

This by-product is mainly composed of glycerol, which is an energetic compound of great assimilation by rumen microorganisms and with extensive metabolism in the liver (Abo El-Nor et al., 2010). In the rumen, glycerol is rapidly metabolized by microorganisms to form short chain fatty acids, mainly propionate and butyrate (Donkin, 2008; AbuGhazaleh et al., 2011). The glycerol disappears almost entirely from the rumen in the first $24 \mathrm{~h}$ (Trabue et al., 2007), but can also be directly absorbed by the epithelium of the digestive system and act as a gluconeogenic substrate in the liver (Krehbiel, 2008).

The fermentation of glycerin may promote better stability to the

\footnotetext{
* Corresponding author. Present address: Department of Agronomy, Federal University of Triângulo Mineiro, Iturama, Minas Gerais, 38280-000, Brazil.

E-mail address: eric.vancleef@uftm.edu.br (E.H.C.B. van Cleef).
} 
rumen environment compared with starch-rich ingredients, mainly by reducing lactic acidosis as a consequence of the increase in the population of lactate-consuming bacteria and undue fermentation (Krueger et al., 2010). However, they may have a detrimental effect on the growth of structural carbohydrate fermenting bacteria (Roger et al., 1992; AbuGhazaleh et al., 2011), resulting in reduced fiber digestibility and methane production (Shin et al., 2012; van Cleef et al., 2015).

Nonetheless, recent studies have shown that the inclusion of high levels of crude glycerin does not impair the consumption, performance or carcass characteristics of feedlot sheep (Gunn et al., 2010a; Gunn et al., 2010b; Gomes et al., 2011). Therefore, it is essential to study high inclusions of crude glycerin in total substitution to corn, with evaluations of rumen fermentation characteristics, to establish an adequate level for a healthier rumen environment.

Therefore, the objective of this study was to evaluate the effects of the inclusion of up to $30 \%$ of crude glycerin (on DM basis) in diets for feedlot crossbred sheep, on ruminal parameters, such as $\mathrm{pH}, \mathrm{NH}_{3}-\mathrm{N}$, VFA concentrations, in situ DM and NDF degradabilities, as well as in vitro greenhouse gas production and DM and nutrients in vitro digestibility.

\section{Materials and methods}

The study was conducted at the Animal Unit of Digestive and Metabolic Studies from the Department of Animal Science of São Paulo State University (Unesp), Jaboticabal, São Paulo, Brazil. The São Paulo State University Institutional Animal Care and Use Committee approved all experimental protocols adopted in the current study (approval number: 06329/14).

\subsection{Animals, diets and experimental design}

Eight ruminally-cannulated crossbred uncastrated male Santa Inês $\times$ Dorper lambs $(64.5 \pm 8.5 \mathrm{~kg}$ and approximately 18 months old) were distributed in a replicated $4 \times 4$ Latin square arrangement of treatments, according to initial body weight. The animals were housed in individual semi-roofed, concrete-surfaced pens $\left(2.5 \mathrm{~m}^{2}\right)$, with individual feed bunks and waterers, and received the experimental diets for 21-d periods, including $14 \mathrm{~d}$ of adaptation, followed by $7 \mathrm{~d}$ of sample collection.

The experimental diets contained $0,10,20$ or $30 \%$ of crude glycerin (on DM basis) and were formulated to be isonitrogenous $(17.7 \% \mathrm{CP}$ / $\mathrm{DM})$ and isoenergetic (2.7-2.8 Kcal ME/kg DM) to supply the requirements of a $20-30 \mathrm{~kg}$ lamb with moderate growth for daily gains of $200 \mathrm{~g}$, according to NRC (2007), and with a roughage:concentrate ratio of 40:60. The dietary treatments were labeled as: G0 (control treatment, containing no crude glycerin), G10 (containing 10\% crude glycerin in diet DM), G20 (containing 20\% crude glycerin in diet DM), and G30 (containing 30\% crude glycerin in diet DM). The crude glycerin totally replaced the corn cracked grain in treatment G30 (Table 1).

The crude glycerin used in this trial contained 95\% DM, $83 \%$ glycerol,1.1\% CP, $6 \%$ salts, $4.8 \%$ other compounds and less than $0.01 \%$ methanol. The concentrate and corn silage were weighed and mixed with crude glycerin at the moment of feeding $(0700$ and $1900 \mathrm{~h})$, delivering $50 \%$ of total mixed ration in each meal. Before subsequent feeding, orts were weighed and approximately $10 \%$ of each animal were sampled to determine DM to adjust feed delivery and to monitor daily dry matter intake.

\subsection{Dry matter intake, rumen $p H$, ammonia nitrogen, and VFA profiles}

The concentrate and corn silage were weighed and mixed with crude glycerin at the moment of feeding, delivering $50 \%$ of total in each meal. Before subsequent feeding, samples of orts of each animal were collected to monitor dry matter daily intake.

Rumen fluid samples were collected on d 15 of each experimental
Table 1

Ingredient and chemical composition of diets containing 0 (G0), 10 (G10), 20 (G20) or $30 \%$ (G30) of crude glycerin.

\begin{tabular}{lllll}
\hline \multirow{2}{*}{ Item } & \multicolumn{2}{l}{ Treatments } & & \\
\cline { 2 - 5 } & G0 & G10 & G20 & G30 \\
\hline Ingredient composition (\%) & & & & \\
Corn silage & 40.0 & 40.0 & 40.0 & 40.0 \\
Corn cracked grain & 30.0 & 20.0 & 10.0 & 0.0 \\
Soybean hulls & 7.8 & 7.2 & 6.3 & 4.5 \\
Soybean meal & 20.6 & 21.0 & 21.6 & 23.1 \\
Urea & 0.6 & 0.9 & 1.1 & 1.3 \\
Crude glycerin & 0.0 & 10.0 & 20.0 & 30.0 \\
Mineral/vitamin premix ${ }^{\mathrm{a}}$ & 0.5 & 0.5 & 0.5 & 0.5 \\
Limestone & 0.5 & 0.5 & 0.5 & 0.5 \\
Bicalcium phosphate & 0.0 & 0.0 & 0.0 & 0.2 \\
Nutrient composition & & & & \\
DM, \% & 65.8 & 66.1 & 66.4 & 66.6 \\
CP, \% & 17.7 & 17.7 & 17.7 & 17.7 \\
ME, Mcal/kg & 2.8 & 2.8 & 2.7 & 2.7 \\
EE, \% & 3.0 & 2.7 & 2.3 & 2.0 \\
aNDF, \% & 34.8 & 33.0 & 31.1 & 28.7 \\
ADF, \% & 19.2 & 18.5 & 17.7 & 16.5 \\
Ca, \% & 0.5 & 0.5 & 0.5 & 0.5 \\
P, \% & 0.3 & 0.3 & 0.3 & 0.3 \\
& & & & \\
\hline
\end{tabular}

a Composition per kg: P (75 g), Ca (223 g), S (10 g), Zn (3 g), Na (60 g), Co (20 mg), I (40 mg), Se (24 mg), F (750 mg), Mg (5 g), Mn (1.8 g), Fe (402 mg), Vit A (312,500 UI), Vit D (50,000 UI), Vit E (437 UI).

period, at $0,2,4,6,8,10$, and $12 \mathrm{~h}$ after feeding to measure $\mathrm{pH}$, and evaluate ammonia nitrogen $\left(\mathrm{NH}_{3}-\mathrm{N}\right)$ and volatile fatty acids (VFA) concentrations. Approximately $500 \mathrm{~g}$ of ruminal contents of each animal were collected from the dorsal and ventral rumen sites, and strained through four layers of cheesecloth to separate liquid and solid phases. The $\mathrm{pH}$ was measured immediately after rumen fluid sampling using a digital $\mathrm{pH}$ meter (model Digimed DM-20; Digicrom Analítica Ltda, São Paulo, SP Brazil), and $\mathrm{NH}_{3}-\mathrm{N}$ concentrations was determined using a micro-Kjeldhal apparatus (model TE-0364; Tecnal Equip. para Laboratórios, Piracicaba, SP, Brazil), with $5 \mathrm{~mL}$ of KOH 2N, and a distillation flux of $2 \mathrm{~mL} / \mathrm{min}$. Samples were centrifuged at $3000 \times g$ for $20 \mathrm{~min}$, and the supernatant was used to determine $\mathrm{NH}_{3}-\mathrm{N}$. The distilled sample was dropped in $10 \mathrm{~mL}$ boric acid solution (2\%), and then titrated with $\mathrm{HCl} 0.005 \mathrm{~N}$.

Approximately $2.0 \mathrm{~mL}$ of rumen fluid was centrifuged twice $\left(12,000 \times g\right.$ for $15 \mathrm{~min}$ at $4{ }^{\circ} \mathrm{C}$ (Sorvall Superspeed RC2-B, Newton, CT, USA)) with formic acid $98-100 \%$ (Merck KGaA). After centrifugation, approximately $0.5 \mathrm{~mL}$ of supernatant was transferred to chromatographic vials. The concentration of VFA was determined by injecting $0.5 \mu \mathrm{L}$ of sample in a gas chromatograph (TRACE 1300, Thermo Scientific, MA, USA) equipped with a HP-FFAP capillary column (19091F-112; $25 \mathrm{~m} ; 0.320 \mathrm{~mm} ; 0.50 \mu \mathrm{m}$; J\&W Agilent Technologies Inc.; Palo Alto, CA, USA). The carrier gas was helium at a flow rate of $1 \mathrm{~mL} / \mathrm{min}$. The oven temperature program was $1 \mathrm{~min}$ at $60^{\circ} \mathrm{C}$, followed by an increase to $200^{\circ} \mathrm{C}$ at a rate of $5^{\circ} \mathrm{C} / \mathrm{min}$. The injector temperature was $270{ }^{\circ} \mathrm{C}$, and the detector temperature was $300^{\circ} \mathrm{C}$. The sample was injected into a split/splitless system (split ratio 1:10). The calibration curve was made using chromatographic standards (Chem Service, West Chester, PA, USA) of acetic acid (99.5\%; CAS 64-19-97), propionic acid (99\%; CAS 79-09-4), isobutyric acid (99\%; CAS 79-31-2), butyric acid (98.7\%; CAS 107-92-6), isovaleric acid (99\%; CAS 503-74-2), and valeric acid (99\%; CAS 109-52-4).

\subsection{In vitro total tract digestibility}

In vitro digestibility of DM and NDF was assessed using the methodology proposed by Holden (1999). On d 21 of each experimental period, approximately $1 \mathrm{~kg}$ of ruminal content were collected from each 
animal, strained through eight layers of cheesecloth, placed into preheated thermos $\left(39^{\circ} \mathrm{C}\right)$, and transported to São Paulo State University Ingredients and Pollutant Gases Laboratory. The ruminal fluid from animals from the same treatment were mixed prior to incubation.

Ankom Daisy ${ }^{\text {II }}$ fermenter (ANKOM Technology Corp., Macedon, NY) was used to evaluate in vitro digestibility of DM and NDF. Ankom F57 filter bags ( $\mathrm{n}=25$; 24 with samples and 1 blank; ANKOM Technology Corp., Macedon, NY) were filled with substrates (the four TRM; 1-mm ground; $0.5 \mathrm{~g}$ ), heat-sealed and placed into fermentation jars. A solution composed of $400 \mathrm{~mL}$ of rumen fluid $(200 \mathrm{~mL}$ from each sheep fed the same diet, in each experimental period), $1330 \mathrm{~mL}$ of buffer A $(10.0 \mathrm{~g} / \mathrm{L}$ $\mathrm{KH}_{2} \mathrm{PO}_{4}, 0.5 \mathrm{~g} / \mathrm{L} \mathrm{MgSO}_{4} \cdot 7 \mathrm{H}_{2} \mathrm{O}, 0.5 \mathrm{~g} / \mathrm{L} \mathrm{NaCl}, 0.1 \mathrm{~g} / \mathrm{L} \mathrm{CaCl}_{2} \cdot 2 \mathrm{H}_{2} \mathrm{O}$ and $0.5 \mathrm{~g} / \mathrm{L}$ urea) and $266 \mathrm{~mL}$ of buffer $\mathrm{B}\left(15.0 \mathrm{~g} / \mathrm{L} \mathrm{Na}_{2} \mathrm{CO}_{3}\right.$ and $1.0 \mathrm{~g} / \mathrm{L}$ $\mathrm{Na}_{2} \mathrm{~S} \cdot 9 \mathrm{H}_{2} \mathrm{O}$ ) was prepared and placed into fermentation jars. The containers were purged with $\mathrm{CO}_{2}$, and placed into the pre-heated $\left(39^{\circ} \mathrm{C}\right)$ Daisy $^{\text {II }}$ fermenter. After 48 -h incubation, $40 \mathrm{~mL}$ of $6 \mathrm{~N} \mathrm{HCl}$ and $8 \mathrm{~g}$ of pepsin $(1: 10,000)$ were added to each digestion jar, and incubated for another 24-h period. The filter bags containing substrates' residues were rinsed and manually washed and dried. Substrates and residues were evaluated for DM (AOAC, 2005; method 967.03) and NDF (Goering and Van Soest, 1970) contents, to calculate DM and NDF in vitro digestibilities.

\subsection{Gas measurements}

At d 19 of each experimental period, approximately $500 \mathrm{~g}$ of ruminal content were collected from each animal, strained through eight layers of cheesecloth, placed into pre-heated thermos $\left(39^{\circ} \mathrm{C}\right)$, and transported to São Paulo State University Ingredients and Pollutant Gases Laboratory. The strained ruminal fluid was gassed with $\mathrm{O}_{2}$-free gas, and mixed with McDougall's buffer, in a ratio of 1:2. Substrates consisted of the same TMR finishing diets G0, G10, G20, and G30 from previous trial. The diets were ground through a 1-mm mesh screen, and $200 \mathrm{mg}$ were used in each penicillin-type 100 -mL glass flask. Fifteen fermentation flasks of each substrate received $20 \mathrm{~mL}$ of McDougall's buffer and $20 \mathrm{~mL}$ of rumen fluid and six blank flasks were prepared without any target substrate. The flasks were purged with $\mathrm{O}_{2}$-free gas, capped with rubber seals, and immediately placed in a $39^{\circ} \mathrm{C}$ prewarmed orbital shaker (SL 222, Solab, Piracicaba, SP, Brazil), equipped with a polystyrene foam structure to hold bottles during the shaking procedure. The incubation was held for $24 \mathrm{~h}$ and, at the end, the flasks were chilled in an ice bath to cease microbial activity. The head-space gas pressure was measured using a digital pressure meter equipped with a pressure transducer (Theodorou et al., 1994). Gas pressure was transformed in gas volume using a methodology adapted from Bueno et al. (2005).

The fermentative gasses were sampled from the flasks after $24 \mathrm{~h}$ of incubation to determine concentrations of $\mathrm{CO}_{2}$ and $\mathrm{CH}_{4}$, using a gas chromatograph (Trace GC Ultra ${ }^{\mathrm{TM}}$, Thermo Scientific, San Jose, CA USA). The GC was equipped with a Porapak column and molecular sieve. The oven temperature was set to $70^{\circ} \mathrm{C}$, and the injector temperature used was $110^{\circ} \mathrm{C}$. The carrier gas used was argon, with $25 \mathrm{~mL} /$ min flow.

After the 24-h incubation period, the sampleś residues were centrifuged $(500 \times g, 10 \mathrm{~min})$, washed three times with deionized $\mathrm{H}_{2} \mathrm{O}$ and dried $\left(105^{\circ} \mathrm{C}\right.$ for $\left.16 \mathrm{~h}\right)$ to calculate $\mathrm{DM}$ disappearance.

\subsection{In situ ruminal degradability}

In situ ruminal degradability of DM and NDF was determined using the methodology proposed by Orskov and Mcdonald (1979). Samples of diets were pre-dried $\left(55^{\circ} \mathrm{C}\right.$ for $72 \mathrm{~h}$ ), ground (silage $=5 \mathrm{~mm}$ and concentrate $=2 \mathrm{~mm}$ ), and $2 \mathrm{~g}$ of total mixed ration were placed into nylon bags $(5 \times 10 \mathrm{~cm}, 50 \mu \mathrm{m}$, Ankom Technology, Macedon, NY). Bags were heat-sealed and reserved until incubation. Each sample was incubated in two replicates along with a blank bag for each incubation time in the rumen of cannulated sheep. The bags were placed into a nylon mesh bag $(20 \times 30 \mathrm{~cm})$ tied with rubber band and pre-soaked in tap water. The incubation times used in this trial were $0,3,6,12,24,48,72$ and $96 \mathrm{~h}$. The incubation was started with time "96 h" and was finished with time " $0 \mathrm{~h}$ ", to remove all bags at the same time at the end of the trial. After the incubation, the bags were removed from the mesh bag and dipped in ice-cold water to cease ruminal microorganisms' activity. Then, bags were rinsed and manually washed until the water becomes clear, and were dried at a forced-air oven $\left(55^{\circ} \mathrm{C}\right.$ for $\left.72 \mathrm{~h}\right)$. After being weighed, the bags were opened, the samples were ground in micro mill (1-mm sieve), and analyzed for DM (AOAC, 2005; method 967.03) and NDF (Goering and Van Soest, 1970).

The DM and NDF degradation kinetics were fitted into the equation: $\mathrm{PD}=\mathrm{a}+\mathrm{b}\left(1-\mathrm{e}^{-\mathrm{ct}}\right)$, where " $\mathrm{D}$ " = ruminal degradability at time " $\mathrm{t}$ ", "a" = the soluble fraction in water, "b" = the insoluble and potentially degradable fraction, "c" = the degradation rate of fraction "b" per hour, and " $\mathrm{t}$ " = the time of incubation. Degradation constants were estimated using the NLIN procedure of SAS (Version 9.4).

\subsection{Statistical analysis}

Data were analyzed as a replicated $4 \times 4$ Latin square design using PROC MIXED of SAS version 9.4 (SAS Institute Inc., Cary, NC). The fixed effect consisted of treatment, and random effects consisted of sheep and period. The statistical model for the trial was as follows: $\mathrm{Y}_{\mathrm{ijkl}}=\mu+\alpha_{\mathrm{i}}+\beta_{\mathrm{j}}+\gamma \mathrm{k}_{(\mathrm{j})}+\lambda \mathrm{l}_{(\mathrm{j})}+\alpha \beta_{(\mathrm{ij})}+\varepsilon_{\mathrm{ijk}}$, where $\mathrm{Y}_{\mathrm{ijkl}}=$ value observed in the plot for treatment $\mathrm{i}$, Latin square $\mathrm{j}$, period $\mathrm{k}$, and cow $\mathrm{l}$; $\mu=$ overall mean; $\alpha i=$ effect of treatment $i ; \beta_{j}=$ effect of Latin square $\mathrm{j} ; \gamma \mathrm{k}_{(\mathrm{l})}=$ effect of period $\mathrm{k}$ within Latin square $\mathrm{j} ; \lambda \mathrm{l}_{(\mathrm{j})}=$ effect of cow 1 within Latin square $j ; \alpha \beta_{(i j)}=$ effect of the interaction treatment $i$ and Latin square $\mathrm{j}$; and $\varepsilon_{\mathrm{ijk}}=$ residual error.

Data of $\mathrm{pH}, \mathrm{NH}_{3}-\mathrm{N}$, and VFA were considered as repeated measures. Several covariance structures were tested and the best one was chosen for each variable, based on Akaike information criterion. The degrees of freedom and tests were adjusted using the option KR. Treatment effects were tested using the following contrasts: (1) linear effect of crude glycerin concentration, (2) quadratic effect of crude glycerin level, and (3) control treatment $\times$ glycerin treatments (effect of the addition of two concentrations of crude glycerin combined versus treatment without addition of the byproduct). Values were reported as least squares means and associated standard errors, and significance was defined as $P<0.05$ and trends as $0.05 \leq P \leq 0.10$.

\section{Results}

\subsection{Dry matter intake, rumen $p H$, ammonia nitrogen, and VFA profiles}

The inclusion of crude glycerin in the diets promoted a tendency for a quadratic effect in DMI $(P=0.09)$, with greater values observed for treatments with 10 and $20 \%$ of the by-product (Table 2 ).

There was no interaction of time of sampling $\times$ treatment for the variables $\mathrm{pH}, \mathrm{NH}_{3}-\mathrm{N}$ and VFA $(P>0.05)$. Thus, only the main effects of treatment and time of sampling were evaluated. The ruminal $\mathrm{pH}$ tended to increase $(P=0.07)$ with the increasing inclusion of crude glycerin in the diets. There was also a tendency for a quadratic effect on the concentration of $\mathrm{NH}_{3}-\mathrm{N}(P=0.06)$, with the lowest values observed for treatments with 10 and $20 \%$ of the by-product (Table 2).

The increasing inclusion of crude glycerin linearly reduced the total molar concentration of VFA $(P<0.0001)$, as well as the molar concentrations of acetic $(P<0.0001)$, butyric $(P=0.0004)$, isobutyric $(P=0.0007)$ and isovaleric $(P=0.003)$ acids (Table 2$)$. No alterations on propionic and valeric acid were observed $(P>0.10)$, however the ratio C2:C3 was linearly reduced when the crude glycerin was included $(P<0.0001)$. 
Table 2

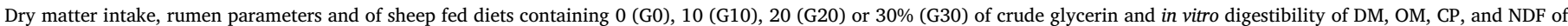
those diets.

\begin{tabular}{|c|c|c|c|c|c|c|c|c|}
\hline \multirow[t]{2}{*}{ Item } & \multicolumn{4}{|c|}{ Treatments } & \multirow[t]{2}{*}{ SE } & \multicolumn{3}{|c|}{ Contrast, $P$-value ${ }^{\mathrm{a}}$} \\
\hline & G0 & G10 & G20 & G30 & & $\mathrm{L}$ & $\mathrm{Q}$ & $0 \times G$ \\
\hline DMI, $g$ & 1237 & 1375 & 1337 & 1205 & 135 & 0.69 & 0.09 & 0.46 \\
\hline $\mathrm{pH}$ & 5.97 & 6.07 & 6.13 & 6.16 & 0.1 & 0.07 & 0.68 & 0.09 \\
\hline $\mathrm{NH}_{3}-\mathrm{N}, \mathrm{mg} / \mathrm{dL}$ & 11.0 & 9.6 & 10.2 & 11.9 & 0.9 & 0.34 & 0.06 & 0.63 \\
\hline Total VFA, mM/L & 40.1 & 37.2 & 27.6 & 23.8 & 6.1 & $<0.0001$ & 0.86 & 0.001 \\
\hline Acetic (C2) & 25.9 & 22.4 & 14.3 & 11.5 & 3.8 & $<0.0001$ & 0.98 & 0.0005 \\
\hline Propionic (C3) & 8.6 & 9.0 & 8.8 & 8.2 & 1.7 & 0.61 & 0.44 & 0.94 \\
\hline Butyric & 4.3 & 4.0 & 3.3 & 2.9 & 0.61 & 0.0004 & 0.89 & 0.006 \\
\hline Isobutyric & 0.26 & 0.22 & 0.17 & 0.15 & 0.05 & 0.0007 & 0.35 & 0.002 \\
\hline Valeric & 0.47 & 0.49 & 0.52 & 0.57 & 0.13 & 0.21 & 0.88 & 0.37 \\
\hline Isovaleric & 0.73 & 0.65 & 0.56 & 0.56 & 0.11 & 0.003 & 0.36 & 0.006 \\
\hline $\mathrm{C} 2 \mathrm{C} 3$ & 2.8 & 2.5 & 1.7 & 1.5 & 0.18 & $<0.0001$ & 0.81 & $<0.0001$ \\
\hline \multicolumn{9}{|c|}{ In vitro Digestibility, \% } \\
\hline DM & 73.6 & 80.2 & 80.7 & 82.7 & 0.51 & 0.01 & 0.28 & 0.007 \\
\hline $\mathrm{OM}$ & 81.5 & 82.0 & 82.6 & 83.4 & 1.19 & 0.26 & 0.86 & 0.43 \\
\hline $\mathrm{CP}$ & 75.1 & 78.4 & 76.5 & 79.0 & 3.21 & 0.51 & 0.90 & 0.46 \\
\hline NDF & 51.5 & 39.6 & 37.7 & 34.2 & 3.78 & 0.008 & 0.38 & 0.006 \\
\hline
\end{tabular}

${ }^{\mathrm{a}} \mathrm{L}=$ Linear, $\mathrm{Q}=$ Quadratic, $0 \times \mathrm{G}=$ Treatment without crude glycerin $\times$ glycerin treatments

\subsection{In vitro total tract digestibility}

The increasing inclusion of crude glycerin linearly increased the in vitro DM digestibility of diets $(P=0.01$, Table 2$)$, and linearly reduced NDF digestibility $(P=0.008)$.

When all treatments with crude glycerin were evaluated against the control one $(0 \times \mathrm{G})$, the same trend was observed for DM and NDF ( $P=0.007$ and $P=0.006$, respectively). In average, DM and NDF digestibility's in treatments with crude glycerin were, respectively, 81.7 and $37.2 \%$, against 73.6 and $51.5 \%$ for control treatment. Additionally, no effect of treatments was observed for in vitro digestibility of OM or CP $(P>0.10)$.

\subsection{Gas measurements}

The increasing inclusion of crude glycerin linearly decreased the total gas and $\mathrm{CO}_{2}$ production $(\mathrm{mL} / \mathrm{g}$ degraded, $P=0.01)$. When both treatments with crude glycerin were compared with G0, a tendency for decreased $\mathrm{CO}_{2}(\mathrm{~mL} / \mathrm{g}$ degraded) production was observed $(P=0.09)$, with the lowest value for $\mathrm{G} 20$ treatment. There were tendencies for linear reduction of $\mathrm{CO}_{2}(\mathrm{~mL} / \mathrm{g})$ and $\mathrm{CH}_{4}(\mathrm{~mL} / \mathrm{g}$ degraded) production ( $P=0.07$ and $P=0.09$, respectively) with increasing inclusion of crude glycerin in the diets.

Table 3

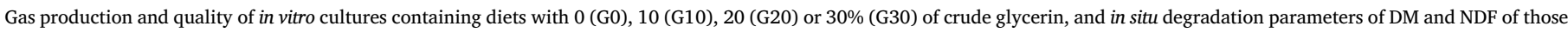
diets in sheep.

\begin{tabular}{|c|c|c|c|c|c|c|c|c|}
\hline \multirow[t]{2}{*}{ Item } & \multicolumn{4}{|c|}{ Treatments } & \multirow[t]{2}{*}{ SE } & \multicolumn{3}{|c|}{ Contrast, $P$-value ${ }^{c}$} \\
\hline & G0 & G10 & G20 & G30 & & $\mathrm{L}$ & $\mathrm{Q}$ & $0 \times G$ \\
\hline \multicolumn{9}{|l|}{ Gas production $^{\mathrm{a}}$} \\
\hline Total, mL/g & 155.5 & 153.8 & 151.1 & 137.9 & 8.9 & 0.13 & 0.48 & 0.40 \\
\hline $\mathrm{CH}_{4}, \mathrm{~mL} / \mathrm{g}$ & 34.4 & 34.0 & 34.0 & 32.5 & 4.1 & 0.55 & 0.82 & 0.71 \\
\hline $\mathrm{CO}_{2}, \mathrm{~mL} / \mathrm{g}$ & 114.4 & 113.2 & 110.7 & 99.6 & 6.5 & 0.07 & 0.39 & 0.32 \\
\hline Total, mL/gd & 267.8 & 258.2 & 250.8 & 220.2 & 14.0 & 0.01 & 0.44 & 0.11 \\
\hline $\mathrm{CH}_{4}, \mathrm{~mL} / \mathrm{gd}$ & 59.7 & 57.7 & 57.0 & 52.2 & 7.0 & 0.09 & 0.71 & 0.36 \\
\hline $\mathrm{CO}_{2}, \mathrm{~mL} / \mathrm{gd}$ & 198.1 & 192.0 & 185.7 & 160.1 & 11.0 & 0.007 & 0.31 & 0.09 \\
\hline \multicolumn{9}{|c|}{ In situ Degradability ${ }^{\mathrm{b}}$} \\
\hline \multicolumn{9}{|c|}{ DM } \\
\hline a, $\%$ & 34.6 & 38.3 & 48.2 & 58.9 & 2.0 & $<0.0001$ & 0.18 & $<0.0001$ \\
\hline $\mathrm{b}, \%$ & 47.4 & 47.6 & 39.3 & 29.4 & 2.3 & $<0.0001$ & 0.13 & 0.002 \\
\hline $\mathrm{kd}, \% / \mathrm{h}$ & 3.5 & 3.1 & 3.0 & 3.2 & 0.4 & 0.48 & 0.27 & 0.25 \\
\hline $\mathrm{PD}, \%$ & 80.0 & 82.6 & 84.5 & 86.5 & 2.4 & 0.0001 & 0.75 & 0.0008 \\
\hline \multicolumn{9}{|l|}{ NDF } \\
\hline a, \% & 14.3 & 14.7 & 15.2 & 15.8 & 0.07 & $<0.0001$ & 0.23 & $<0.0001$ \\
\hline $\mathrm{b}, \%$ & 42.7 & 50.4 & 52.3 & 52.0 & 6.0 & 0.01 & 0.11 & 0.004 \\
\hline $\mathrm{kd}, \% / \mathrm{h}$ & 3.6 & 2.5 & 2.5 & 2.6 & 0.5 & 0.05 & 0.09 & 0.010 \\
\hline $\mathrm{PD}, \%$ & 54.5 & 59.3 & 61.4 & 60.4 & 6.5 & 0.10 & 0.27 & 0.061 \\
\hline
\end{tabular}

${ }^{\mathrm{a}} \mathrm{mL} / \mathrm{g}=$ production in $\mathrm{mL}$ per gram, $\mathrm{mL} / \mathrm{gd}=$ gas production in $\mathrm{mL}$ per gram degraded.

${ }^{\mathrm{b}} \mathrm{a}=$ soluble, $\mathrm{b}=$ insoluble but potentially degradable, $\mathrm{kd}=$ fermentation rate, $\mathrm{PD}=$ potential degradability.

${ }^{\mathrm{c}} \mathrm{L}=$ Linear, $\mathrm{Q}=$ Quadratic, $0 \times \mathrm{G}=$ Treatment without crude glycerin $\times$ glycerin treatments. 


\subsection{In situ ruminal degradability}

The increasing inclusion of crude glycerin resulted in a linear increase of soluble fraction ("a") of DM of the diets $(P<0.0001$, Table 3). Concomitantly, a linear decrease of insoluble but potentially degradable fraction ("b") of DM of the diets $(P<0.0001)$ was observed with increasing concentrations of crude glycerin.

The DM degradation rate of the diets was not influenced by the inclusion of crude glycerin in the diets. However, the potential degradation $(P<0.0001)$ and the effective degradation, considering a passage rate of $2 \% / \mathrm{h}(P<0.0001), 5 \% / \mathrm{h}(P<0.0001)$ and $8 \% / \mathrm{h}$ $(P<0.0001)$ were markedly and linearly increased.

The fraction "a" of NDF of the diets was linearly increased $(P<0.0001)$, while the fraction "b" was linearly increased $(P<0.01)$, ranging from $42.7 \%$ in control treatment to $52 \%$ in treatment with $30 \%$ crude glycerin (Table 3 ).

The NDF degradation rate was decreased in treatments containing crude glycerin compared with control treatment $(0 \times \mathrm{G}, P=0.01)$. Moreover, there was a tendency for increase of the potential degradation of NDF $(P=0.06)$ when crude glycerin was added.

\section{Discussion}

\subsection{Dry matter intake, rumen $\mathrm{pH}$, ammonia nitrogen, and VFA profiles}

High concentrations of crude glycerin change the physical form of the diets, which it becomes more viscous due to crude glycerin high viscosity (approximately $8.5 \mathrm{cs}$, Thompson and He, 2006). At some point, it could help aggregation of particles and facilitate the feed intake. However, in practice, inclusions of more than $20 \%$ of crude glycerin, especially in tropical conditions, do not appear to be a good strategy because the by-product becomes more liquid, resulting in accumulation of the ingredient in the bottom of the feed bunk.

The quadratic effect observed for DMI agrees with the study conducted by Parsons et al. (2009), who fed beef heifers 0, 2, 4, 8, 12, or $16 \%$ crude glycerin and observed increased DMI for intermediate levels of crude glycerin and a decrease when $16 \%$ of the by-product were added. However, Chanjula et al. (2014) feeding goats up to $20 \%$ crude glycerin, and Gomes et al. (2011), feeding lambs up to $30 \%$ crude glycerin did not find any difference in DMI of experimental animals. On the other hand, in some studies a drop in DMI is observed, even using low concentrations of crude glycerin for beef cattle and goats (Schneider, 2010; Chanjula et al., 2016). This discrepancy in DMI is probably due to differences in crude glycerin used, as well as the roughage:concentrate ratio, amount of dietary starch and fiber and the tolerance and acceptability of the ingredient by each animal species.

The tendency of linearly increased ruminal $\mathrm{pH}$ observed in present trial agrees with Polizel et al. (2013), who fed lambs up to $20 \%$ crude glycerin in high concentrate diets and also observed a linear increase in rumen $\mathrm{pH}$ values. The increase occurred probably due to the linear decrease observed in total VFA concentrations (40.1 in G0 and $23.8 \mathrm{mM} / \mathrm{L}$ in G30). However, in most of findings reported from studies using high concentrations of crude glycerin (up to 20\%), authors did not observe alterations of rumen $\mathrm{pH}$ values (Chanjula et al., 2014; Favaro et al., 2015). Low ruminal pH may decrease DMI, fiber digestibility, and microbial yield and thus decrease animal production (Allen, 1997).

Although the tendency for a quadratic effect of rumen $\mathrm{NH}_{3}-\mathrm{N}$ concentrations, only the treatment containing $10 \%$ crude glycerin $(9.6 \mathrm{mg}$ / $\mathrm{dL}$ ) did not reach the minimum value considered for the maximization of ruminal digestion which is $10 \mathrm{mg} / \mathrm{dL}$, according to Leng (1990). Previous studies did not report differences in rumen $\mathrm{NH}_{3}-\mathrm{N}$ concentrations, when 10.8 (Abo El-Nor et al., 2010) or 21\% (Avila et al.,
2011) crude glycerin were used in in vitro trials. The $\mathrm{NH}_{3}-\mathrm{N}$ concentrations may be also related to the increased level of urea, which was greater with the increasing inclusion of crude glycerin in the diets (Table 1).

The effects of crude glycerin inclusion on total and individual VFA are significant. Although no changes in molar concentrations of propionic and valeric acids were observed, the proportion of both VFA in relation to total VFA was notably altered (from $21.4 \%$ to $34.4 \%$ for propionic acid and from 1.2 to $2.4 \%$ for valeric acid). Total VFA decrease was also observed by Polizel et al. (2013), but it was not observed by Ramos and Kerley (2012), feeding continpous fermenters, nor by Chanjula et al. (2014), working with goats.

Although the absolute yield of propionate was not affected by the increasing inclusion of crude glycerin, a linear increase in the proportion of propionate was observed. The change in the relative proportion of propionate was, probably, due to fermentation characteristics of glycerin, which is fermented, mainly by bacteria of genus Selenomonas and it is mostly used by animals in the first 4 or $6 \mathrm{~h}$ after ingestion (Ferraro et al., 2009; Mach et al., 2009). On the other hand, the linear decrease in acetic acid concentration contributed to the linear decrease in C2:C3 ratio, and was due, mainly, to the deleterious effect of crude glycerin on rumen fibrolytic microorganisms, as described by Abo ElNor et al. (2010) and confirmed by the decrease in fiber fraction in vitro total tract digestibility observed in the present study. Previous studies, using even low concentrations of crude glycerin fed to dairy cows reported commensurable results (Boyd et al., 2013).

\subsection{In vitro total tract digestibility}

The linear increase in IVDMD obtained in this trial disagrees with results reported by Abo El-Nor et al. (2010), which fed in vitro fermenters up to $10 \%$ crude glycerin and did not observe any difference in this variable. Chanjula et al. (2014) feeding up to $20 \%$ crude glycerin to goats, also did not observe effects on DM digestibility. However, most of results in literature are discrepant due to the differences in feed ingredients, diets, and methods of analysis used.

Wang et al. (2009) fed steers low concentrations of glycerol (up to $3.3 \%$ ) and observed a linear increase of OM and CP total tract digestibilities. These authors suggest that glycerol modulates the digestive microorganisms or enzymes in a dose-dependent manner, promoting changes in ruminal environment and, consequently, the digestibility of nutrients.

The decreased NDF in vitro total tract digestibility observed in glycerin treatments is consistent with results reported previously when beef cattle were fed crude glycerin at up to 30\% (van Cleef et al., 2014), and even at low concentrations, as demonstrated by Parsons and Drouillard (2010), which included up to $4 \%$ in diets for beef heifers and observed linear reduction of fiber digestibility.

The same effect was observed when dairy cows were fed up to $15 \%$ glycerin (Donkin et al., 2009; Shin et al., 2012). Glycerin inclusion reduces the number of microorganisms involved in fiber digestion (Roger et al., 1992), promoting a reduced acetic acid concentration in the rumen, as observed in present trial. However, the mechanisms involved are not completely clarified, and are probably related to changes in rumen osmolarity, the physical protection of the feed particles, or the competition or preference for another substrate by microorganisms, and in this case the glycerol (van Cleef et al., 2014).

\subsection{Gas measurements}

The linear reduction of total gas $\left(\mathrm{mL} / \mathrm{g}\right.$ degraded) and $\mathrm{CO}_{2}$ production $(\mathrm{mL} / \mathrm{g}$ and $\mathrm{mL} / \mathrm{g}$ degraded) observed with increasing inclusion of crude glycerin is probably due to the lower ruminal fermentation and 
VFA formation of glycerin treatments (Table 2). According to Owens and Basalan (2016), the VFA formation is directly associated with the amount of gas production in the rumen, as feed fermentation results in VFA, as well as $\mathrm{CO}_{2}$ and $\mathrm{H}_{2}$.

Previous studies have shown that the total gas production, resulted from crude glycerin inclusion in the diets, is reduced mainly by the reduction of ruminal $\mathrm{CO}_{2}$ (Lee et al., 2011; van Cleef et al., 2015). Homem Junior et al. (2017) evaluated in vitro gas production of different feed ingredients and observed that crude glycerin promoted less gas compared with corn grain, citrus pulp, soybean hulls and corn silage, mainly by the lowest ruminal $\mathrm{CO}_{2}$ production. In the present trial, the production of $\mathrm{CO}_{2}$ (mL/g degraded) were 3.1 (G10), 6.3 (G20), and $19.2 \%$ (G30) lesser than the treatment without crude glycerin, reflecting in lesser values of total gas production for glycerin treatments.

The tendency for a linear reduction of $\mathrm{CH}_{4}$ production $(\mathrm{mL} / \mathrm{g}$ degraded) observed can be due to a detrimental effect of crude glycerin on the growth of structural carbohydrate fermenting bacteria (AbuGhazaleh et al., 2011), resulting in reduced fiber digestibility and $\mathrm{CH}_{4}$ production, when the by-product is fed at up to 10 or $30 \%$, respectively to dairy or beef cattle (Shin et al., 2012; van Cleef et al., 2015). And the linear reduction of molar concentration of acetic acid in the rumen, observed in this trial, support that hypothesis (Table 2).

\subsection{In situ ruminal degradability}

The increase observed in fraction "a" of dry matter of the diets could be explained by the high solubility of crude glycerin, as reported by Donkin (2008). Thus, increasing a highly soluble substrate, it is expected to increase soluble fraction of DM of total diet, and consequently, to decrease, proportionally, its undegradable fraction. In addition, with the inclusion of crude glycerin in the diets, the concentration of acid detergent fiber (ADF) of experimental diets linearly decreased, ranging from $18.2 \%$ in control treatment (without crude glycerin addition), and $15.5 \%$ for G30. This decrease was due to the removal of corn cracked grain $(4.5 \% \mathrm{ADF})$ and of soybean hulls $(50 \%$ $\mathrm{ADF}$ ), with the concomitant addition of crude glycerin, which does not contain any fiber in its composition.

Previous study evaluating degradation of OM and NDF reported no differences, when crude glycerin was added at up to $12 \%$ in diets for lambs in vitro (Peripolli et al., 2014). However, even at low concentration crude glycerin seems affect in situ ruminal degradation parameters of steers. Wang et al. (2009), reported a quadratic effect on the degradation rate of fraction " $\mathrm{b}$ " of DM and NDF with increasing concentration of crude glycerin supplementation for steers.

In the present study, the linear increase of fraction "a" of NDF was probably due to the increasing contribution, in percentage, of soybean meal in the glycerin diets, which presents a NDF solubility of around 32\% (Valadares Filho et al., 2017).

The tendency of increased potential degradation is against the premise that crude glycerin promotes a negative effect on the digestibility and ruminal degradability of the fibrous fraction of the diets and ingredients, when the animals were fed crude glycerin as energy source (Abo El-Nor et al., 2010; D'Aurea, 2010; Schneider, 2010; van Cleef, 2012; van Cleef et al., 2014), and it might be also that the high solubility of the crude glycerin compensates for the decrease in fiber degradation, which ends up with higher total degradability of the diet.

\section{Conclusions}

The replacement of corn cracked grain by crude glycerin (up to $30 \%$ DM) changes rumen fermentation parameters, decreasing VFA production, in vitro total gas production and $\mathrm{CH}_{4}$. Additionally, the potential and effective degradation as well as the in vitro DM digestibility of diets are improved, while fiber digestibility is impaired.

\section{Conflicts of interest}

The authors declare no known conflict of interest.

\section{Acknowledgments}

Authors thank the undergraduate students and staff from Animal Unit of Digestive and Metabolic Studies from the Department of Animal Science of São Paulo State University for animal care, Caramuru Alimentos Inc. for the donation of part of ingredients used in this research, and Fundação de Amparo à Pesquisa do Estado de São Paulo for the scholarships provided (Grant numbers: 2013/18118-8 and 2015/ 04595-4).

\section{References}

ANP, Agência Nacional do Petróleo, 2017. Statistical yearbook 2017. http://www.anp. gov.br/wwwanp/publicacoes/anuario-estatistico/3819-anuario-estatistico-2017/. (Accessed 19 September 2017).

Association of Official Analytical Chemists, 2005. Official Method of Analysis, 18th edition. AOAC International, Gaithersburg, MD, USA.

Abo El-Nor, S., AbuGhazaleh, A.A., Potu, R.B., Hastings, D., Khattab, M.S.A., 2010. Effects of differing levels of glycerol on rumen fermentation and bacteria. Anim. Feed Sci. Technol. 162, 99-105.

AbuGhazaleh, A.A., Abo El-Nor, S., Ibrahim, S.A., 2011. The effect of replacing corn with glycerol on ruminal bacteria in continuous culture fermenters. J. Anim. Physiol. Anim. Nutr. (Berl.) 95, 313-319.

Allen, M.S., 1997. Relationship between fermentation acid production in the rumen and the requirement for physically effective fiber. J. Dairy Sci. 80, 1447-1462.

Almeida, M.T.C., Ezequiel, J.M.B., Paschoaloto, J.R., Perez, H.L., de Carvalho, V.B., Castro Filho, E.S., van Cleef, E.H.C.B., 2017. Effects of high concentrations of crude glycerin in diets for feedlot lambs: feeding behaviour, growth performance, carcass and non-carcass traits. Anim. Prod. Sci. http://dx.doi.org/10.1071/AN16628.

Avila, J.S., Chaves, A.V., Hernandez-Calva, M., Beauchemin, K.A., McGinn, S.M., Wang, Y., Harstad, O.M., McAllister, T.A., 2011. Effects of replacing barley grain in feedlot diets with increasing levels of glycerol on in vitro fermentation and methane production. Anim. Feed Sci. Technol. 166-167, 265-268.

Boyd, J., Bernard, J.K., West, J.W., 2013. Effects of feeding different amounts of supplemental glycerol on ruminal environment and digestibility of lactating dairy cows. J. Dairy Sci. 96, 470-476.

Bueno, I.C.S., Cabral, S.L.S., Gobbo, S.P., Louvandini, H., Vitti, D.M.S.S., Abdalla, A.L., 2005. Influence of inoculum source in a gas production method. Anim. Feed Sci. Technol. 123, 95-105.

Carvalho, V.B., Leite, R.F., Almeida, M.T., Paschoaloto, J.R., Carvalho, E.B., Lanna, D.P., Perez, H.L., Van Cleef, E.H., Homem Junior, A.C., Ezequiel, J.M., 2015. Carcass characteristics and meat quality of lambs fed high concentrations of crude glycerin in low-starch diets. Meat Sci. 110, 285-292.

Chanjula, P., Pakdeechanuan, P., Wattanasit, S., 2014. Effects of dietary crude glycerin supplementation on nutrient digestibility, ruminal fermentation, blood metabolites, and nitrogen balance of goats. Asian-Aust. J. Anim. Sci. 27, 365-374.

Chanjula, P., Pongprayoon, S., Kongpan, S., Cherdthong, A., 2016. Effects of crude glycerin from waste vegetable oil supplementation on feed intake, ruminal fermentation characteristics, and nitrogen utilization of goats. Trop. Anim. Health Prod. 48, 995-1004.

D'Aurea, A.P., 2010. Glycerin, a Biodiesel Waste, in Finishing Diets for Nelore Heifers. Sao Paulo State University, Repositório Institucional UNESP, Jaboticabal, SP (Accessed 23 June 2017). https://repositorio.unesp.br/handle/11449/95259/.

Donkin, S.S., Koser, S.L., White, H.M., Doane, P.H., Cecava, M.J., 2009. Feeding value of glycerol as a replacement for corn grain in rations fed to lactating dairy cows. J. Dairy Sci. 92, 5111-5119.

Donkin, S.S., 2008. Glycerol from biodiesel production: the new corn for dairy cattle. Rev. Bras. Zootecn. 37, 280-286.

Favaro, V.R., Ezequiel, J.M.B., D'Aurea, A.P., van Cleef, E.H.C.B., Sancanari, J.B.D., Santos, V., Homem, A.C., 2015. Glycerin in cattle feed: intake, digestibility, and ruminal and blood parameters. Semin-Cienc. Agrar. 36, 1495-1505.

Ferraro, S.M., Mendoza, G.D., Miranda, L.A., Gutierrez, C.G., 2009. In vitro gas production and ruminal fermentation of glycerol: propylene glycol and molasses. Anim. Feed Sci. Technol. 154, 112-118.

Goering, H.K., Van Soest, P.J., 1970. Forage Fiber Analyses (Apparatus, Reagents, Procedures, and Some Applications). Agric. Res. Serv., USDA, Washington, DC.

Gomes, M.A.B., Moraes, G.V., Mataveli, M., Macedo, F.D.F., Carneiro, T.C., Rossi, R.M., 2011. Performance and carcass characteristics of lambs fed on diets supplemented with glycerin from biodiesel production. Rev. Bras. Zootecn. 40, 2211-2219.

Gunn, P., Schultz, A., Van Emon, M., Neary, M., Lemenager, R., Rusk, C., Lake, S., 2010a. Effects of elevated crude glycerin concentrations on feedlot performance, carcass characteristics, and serum metabolite and hormone concentrations in finishing ewe and wether lambs1. Prof. Anim. Sci. 26, 298-306.

Gunn, P.J., Neary, M.K., Lemenager, R.P., Lake, S.L., 2010b. Effects of crude glycerin on performance and carcass characteristics of finishing wether lambs. J. Anim. Sci. 88, 1771-1776.

Holden, L.A., 1999. Comparison of methods of in vitro dry matter digestibility for ten 
feeds. J. Dairy Sci. 82, 1791-1794.

Homem Junior, A.C., Ezequiel, J.M.B., Fávaro, V.R., Almeida, M.T.C., Paschoaloto, J.R., D'Áurea, A.P., Carvalho, V.B., Nocera, B.F., Cremasco, L.F., 2017. Methane production by in vitro ruminal fermentation of feed ingredients. Semin-Cienc. Agrar. 38, 877-884.

Krehbiel, C., 2008. Ruminal and physiological metabolism of glycerin. J. Anim. Sci 86, 392.

Krueger, N.A., Anderson, R.C., Tedeschi, L.O., Callaway, T.R., Edrington, T.S., Nisbet, D.J., 2010. Evaluation of feeding glycerol on free-fatty acid production and fermentation kinetics of mixed ruminal microbes in vitro. Bioresour. Technol. 101, $8469-8472$

Lee, S.Y., Lee, S.M., Cho, Y.B., Kam, D.K., Lee, S.C., Kim, C.H., Seo, S., 2011. Glycerol as a feed supplement for ruminants: in vitro fermentation characteristics and methane production. Anim. Feed Sci. Technol. 166-167, 269-274.

Leng, R.A., 1990. Factors affecting the utilization of 'poor-quality'forages by ruminants particularly under tropical conditions. Nutr. Res. Rev. 3, 277-303.

Mach, N., Bach, A., Devant, M., 2009. Effects of crude glycerin supplementation on performance and meat quality of Holstein bulls fed high-concentrate diets. J. Anim. Sci. 87, 632-638.

NRC, 2007. Nutrient Requeriments of Small Ruminants: Sheep, Goats, Cervids, and New World Camelids, 7th edition. The National Academic Press, Washington, DC.

OECD/FAO, 2016. OECD-FAO Agricultural Outlook 2016-2025. OECD Publishing, Paris (Accessed 23 October 2017). https://doi.org/10.1787/agr_outlook-2016-en/.

Orskov, E.R., Mcdonald, I., 1979. Estimation of protein degradability in the rumen from incubation measurements weighted according to rate of passage. J. Agric. Sci. 92, 499-503.

Owens, F.N., Basalan, M., 2016. Ruminal fermentation. In: Millen, D.D., Arrigoni, M.D.B., Pacheco, R.D.L. (Eds.), Rumenology. Springer Nature, Switzerland, pp. 63-102.

Parsons, G., Drouillard, J., 2010. Effects of crude glycerin on ruminal metabolism and diet digestibility in flaked-corn finishing diets. J. Anim. Sci. 88, 31.

Parsons, G.L., Shelor, M.K., Drouillard, J.S., 2009. Performance and carcass traits of finishing heifers fed crude glycerin. J. Anim. Sci. 87, 653-657.

Peripolli, V., Prates, Ê.R., Barcellos, J.O.J., Wilbert, C.A., Camargo, C.M., Lopes, R.B., Costa Junior, J.B.G., 2014. Effect of crude glycerol on in-vitro ruminal fermentation kinetics. Ver. Bras. Saúde Prod. Anim. 15, 172-181.

Polizel, D.M., Gentil, R.S., Ferreira, E.M., Souza, R.A., Freire, A.P.A., Faleiro Neto, J.A. Pires, A.V., Susin, I., 2013. Rumen metabolism in lambs fed high-concentrate diets containing increasing levels of crude glycerin. J. Anim. Sci. 91 (Suppl. 2), 96.

Ramos, M.H., Kerley, M.S., 2012. Effect of dietary crude glycerol level on ruminal fermentation in continuous culture and growth performance of beef calves. J. Anim. Sci. 90, 892-899.

Roger, V., Fonty, G., Andre, C., Gouet, P., 1992. Effects of glycerol on the growth, adhesion, and cellulolytic activity of rumen cellulolytic bacteria and anaerobic fungi. Curr. Microbiol. 25, 197-201.

Schneider, C.J., 2010. Crude Glycerin in Feedlot Cattle Diets and as a Solvent in Maillard Reaction Processes Intended for Manufacturing Value-added Protein Meals. Department of Animal Sciences and Industry. Kansas State University, Hale Library, Manhattan, KS (Accessed 23 June 2017). http://krex.k-state.edu/dspace/handle/ $2097 / 4648$.

Shin, J.H., Wang, D., Kim, S.C., Adesogan, A.T., Staples, C.R., 2012. Effects of feeding crude glycerin on performance and ruminal kinetics of lactating Holstein cows fed corn silage- or cottonseed hull-based, low-fiber diets. J. Dairy Sci. 95, 4006-4016.

Theodorou, M.K., Williams, B.A., Dhanoa, M.S., Mcallan, A.B., France, J., 1994. A simple gas-production method using a pressure transducer to determine the fermentation kinetics of ruminant feeds. Anim. Feed Sci. Technol. 48, 185-197.

Thompson, J.C., He, B.B., 2006. Characterization of crude glycerol from biodiesel production from multiple feedstocks. Appl. Eng. Agric. 22, 261-265.

Trabue, S., Scoggin, K., Tjandrakusuma, S., Rasmussen, M.A., Reilly, P.J., 2007. Ruminal fermentation of propylene glycol and glycerol. J. Agric. Food Chem. 55, 7043-7051.

Valadares Filho, S.B., Machado, P.A.S., Chizzotti, M.L., Amaral, H.F., Magalhães, K.A., Rocha Junior, V.R., Capelle, E.R., 2017. CQBAL 3.0. Brazilian Tables of Feed Composition for Cattle. http://cqbal.agropecuaria.ws/. (Accessed 23 June 2017).

van Cleef, E.H.C.B., Ezequiel, J.M.B., D'Aurea, A.P., Favaro, V.R., Sancanari, J.B.D., 2014. Crude glycerin in diets for feedlot Nellore cattle. Rev. Bras. Zootecn. 43, 86-91.

van Cleef, E.H.C.B., Almeida, M.T.C., Perez, H.L., van Cleef, F.O.S., Silva, D.A.V., Ezequiel, J.M.B., 2015. Crude glycerin changes ruminal parameters, in vitro greenhouse gas profile, and bacterial fractions of beef cattle. Livest. Sci. 178, 158-164.

van Cleef, E., D'Aurea, A.P., Favaro, V.R., van Cleef, F.O.S., Barducci, R.S., Almeida, M.T.C., Machado Neto, O.R., Ezequiel, J.M.B., 2017. Effects of dietary inclusion of high concentrations of crude glycerin on meat quality and fatty acid profile of feedlot fed Nellore bulls. PLoS One 12, e0179830.

van Cleef, E.H.C.B., 2012. Crude Glycerin in Diets for Nelore Feedlot Cattle. Sao Paulo State University, Repositório Institucional UNESP, Jaboticabal, SP (Accessed 23 June 2017). https://repositorio.unesp.br/handle/11449/104075/.

Wang, C., Liu, Q., Huo, W.J., Yang, W.Z., Dong, K.H., Huang, Y.X., Guo, G., 2009. Effects of glycerol on rumen fermentation, urinary excretion of purine derivatives and feed digestibility in steers. Livest. Sci. 121, 15-20. 